Fatoba, O.O. et al. (2013). Laboratory study on the mobility of major species in fly ash-brine codisposal systems: up-flow percolation test.

Water, Air \& Soil Pollution, 224: 1724

\title{
Laboratory study on the mobility of major species in fly ash-brine co-disposal systems: up-flow percolation test
}

\author{
O. O. Fatoba, L. F. Petrik, R. O. Akinyeye, W. M. Gitari and E. I. Iwuoha
}

\begin{abstract}
Apart from the generation of fly ash, brine (hyper-saline wastewater) is also a waste material generated in South African power stations as a result of water re-use. These waste materials contain major species such as $\mathrm{Al}, \mathrm{Si}, \mathrm{Na}, \mathrm{K}, \mathrm{Ca}, \mathrm{Mg}, \mathrm{Cl}$ and $\mathrm{SO}_{4}$. The co-disposal of fly ash and brine has been practiced by some power stations in South Africa with the aim of utilizing the fly ash to capture the salts in brine. The effect of the chemical interaction of the species contained in both fly ash and brine, when co-disposed, on the mobility of species in the fly ash-brine systems is the focus of this study. The up-flow percolation test was employed to determine the mobility of some major species in the fly ash-brine systems. The results of the analysed eluates from the up-flow percolation tests revealed that some species such as $\mathrm{Al}$, $\mathrm{Ca}$ and $\mathrm{Na}$ were leached from the fly ash into the brine solution while some species such as $\mathrm{Mg}, \mathrm{Cl}$ and $\mathrm{SO}_{4}$ were removed to some extent from the brine solution during the interaction with fly ash. The $\mathrm{pH}$ of the up-flow percolation systems was observed to play a significant role on the mobility of major species from the fly ash-brine systems. The study showed that some major species such as $\mathrm{Mg}, \mathrm{Cl}$ and $\mathrm{SO}_{4}$ could be removed from brine solution using fly ash when certain amount of brine percolates through the ash.
\end{abstract}

\section{Introduction}

The combustion of coal for power generation is on the increase due to the increase in demand for electricity globally. Huge amounts of fly ash are produced as a result of the increase in coal combustion. According to US Coal Combustion Product Production \& Use Survey Report, US power plants produced about 6o million tons of fly ash in 2011, out of which nearly $39 \%$ was beneficially used (ACAA 2011). South African power utilities generate significant quantities (about $40 \mathrm{Mt}$ ) of fly ash annually of which the power stations operated by ESKOM South Africa generate $25 \mathrm{Mt}$ of the fly ash annually (ESKOM Report 2013). Out of the fly ash generate in South Africa per annum, less than $10 \%$ is beneficially utilized. The fact remains that, despite its beneficial use for agricultural purposes, waste stabilization, additive to cement, road construction among others (Iyer and Scott 2001; Kumpiene et al. 2006; Foner et al. 1999), significant amounts of fly ash are being disposed in ash dump. Fly ash contains major and minor species such as $\mathrm{Ca}, \mathrm{Na}, \mathrm{Mg}, \mathrm{K}, \mathrm{SO}_{4}, \mathrm{Cl}, \mathrm{Fe}$, $\mathrm{As}, \mathrm{Pb}, \mathrm{Cu}, \mathrm{Cr}, \mathrm{Mo}, \mathrm{Mn}$, etc., and these species could leach out in significant quantities from fly ash when in contact with aqueous solution (Ilic et al. 2003; Baba and Kaya 2004; 
Polettini and Pomi 2004; Adriano et al. 1980). The disposal of fly ash has been a major concern to coal-fired power stations due to the possible release of contaminants to the surrounding soils, surface and groundwater. Apart from the fly ash generated in the power stations in South Africa, brine (a hyper-saline wastewater), is also generated in significant quantities in water treatment circuits. Brine contains some major and trace species such as $\mathrm{Na}$, $\mathrm{Mg}, \mathrm{K}, \mathrm{SO}_{4}, \mathrm{Cl}, \mathrm{As}, \mathrm{Pb}, \mathrm{Cu}, \mathrm{Se}$ and $\mathrm{Cr}$, in significant quantities. The disposal of brine is regulated due to its chemical composition thereby causing some power stations to co-dispose fly ash and brine with the aim of using fly ash to capture the species in brine. The leaching behaviour of major and minor species from coal fly ash and municipal solid waste incineration ash has been widely studied (Gitari et al. 2009; Meima and Comans 1999; Hyks et al. 2009) in order to assess the environmental implications of their utilization and disposal. Despite several studies on the release of species from fly ash when in contact with water and acid mine drainage (Baba and Kaya 2004; Polettini and Pomi 2004; Gitari et al. 2006), adequate attention has not been given to understanding the mobility of some species when fly ash is in contact with brine solution. This study is aimed at understanding the chemical interactions and mobility of major species when fly ash and brine are codisposed. The up-flow percolation test was employed to simulate, to some extent, a codisposal scenario where fly ash and brine are mixed to form a slurry after which brine solution is percolated through the fly ash-brine system on a continuous basis. This approach enables the evaluation of the temporal evolution of $\mathrm{pH}$ and the major species over a given period of time.

\section{Materials and Method \\ 2.1 Fly Ash and Brine}

Fresh fly ash samples were collected from two South African coal-fired power utilities. The power utilities were coded as SC and TC. Fresh fly ash from SC power station was collected directly from the hoppers while the fly ash from TC was collected from the conveyor belt taking the ash to the ash dump. The TC fly ash used in this study was preconditioned with about $16 \%$ brine solution to suppress dust before the ash was sampled (Fatoba et al. 2011). There was no access to the fresh fly ash directly from the hopper because of the regulations of the power station. The fly ash samples were stored in sealed plastic containers. The plastic bags were filled to the top to exclude as much air as possible and then sealed up. The plastic bags containing the fly ash samples were stored in a dark cool cupboard far away from sources of heat, out of direct sunlight and away from fluctuating temperature.

The brine sample used in this study was collected from the highly saline retentate stream of the reverse osmosis desalination plant at $\mathrm{TC}$ power station. The choice of the brine sample from TC power station was as a result of the higher concentration of the major elements compared to the brine generated at SC power station. The brine sample was stored in plastic containers, tightly closed and stored in the refrigerator at $4{ }^{\circ} \mathrm{C}$.

\subsection{Up-flow Percolation Test}

The up-flow percolation test was carried out according to European standard method prEN14405 (CEN 2003) (details in Fatoba 2010). Columns of height $30 \mathrm{~cm}$ and internal 
diameter $5 \mathrm{~cm}$ were designed for the up-flow percolation test. The column, including top and bottom sections, and filters were rinsed with $1 \mathrm{M}$ nitric acid and de-mineralized water consecutively. The column was packed with the fly ash sample to the height of $25 \pm 5 \mathrm{~cm}$ and then weighed to determine the weight of the fly ash in the column (Fig. 1). The column was saturated with brine using a peristaltic pump. The saturated fly ash was left standing for a period of 3 days in order to equilibrate the systems (CEN 2003). After the equilibration period, fresh brine was continuously pumped into the column using a peristaltic pump pumping at a flow rate of $12 \mathrm{~mL} / \mathrm{h}$. The outlet hose was connected to the collection bottle and samples were taken at different times for analyses over a period of time until a cumulative L/S 80 was attained. At each leachate collection, time and volume of the eluate fraction was recorded in order to calculate the liquid/solid ratio and other necessary calculations at the end of the experiment. The $\mathrm{pH}$ and $\mathrm{EC}$ of the eluate were measured immediately after the eluates were taken. Samples were thereafter preserved with dilute $\mathrm{HNO}_{3}$ for analysis of metals by inductively coupled-mass spectrometry for major elements and un-acidified samples diluted accordingly for $\mathrm{SO}_{4}{ }^{2-}$ and $\mathrm{Cl}^{-}$analysis by ion chromatography. Samples were refrigerated at $4{ }^{\circ} \mathrm{C}$ until analysis. The up-flow percolation tests were carried out in duplicate.

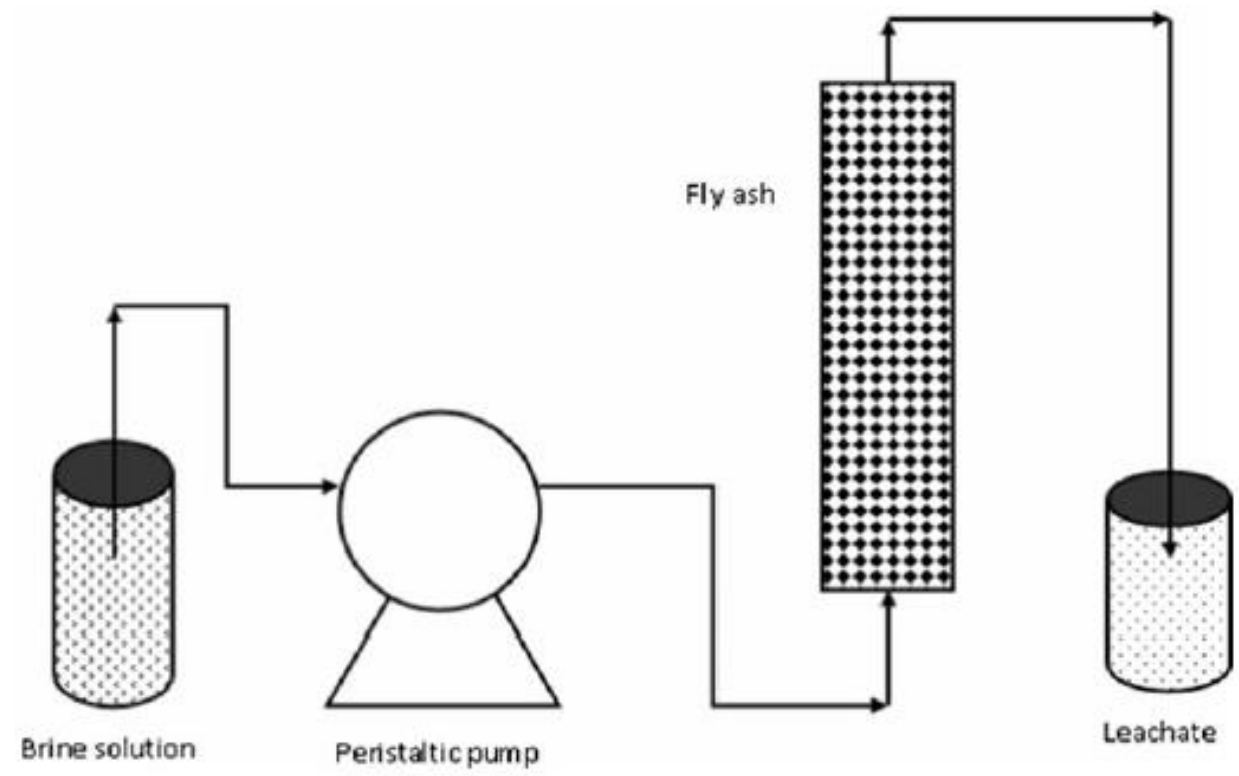

Fig. 1 Schematic diagram of up-flow percolation test

\section{Results and Discussion}

\subsection{Major Elements in Fly Ash}

The major elemental composition of the fresh fly ashes from SC and TC power stations showed that the ashes contain high concentrations of $\mathrm{Al}, \mathrm{Si}, \mathrm{Ca}, \mathrm{Mg}$ and $\mathrm{S}\left(\mathrm{SO}_{4}\right)$ (Table 1 ). The comparison of the fly ashes showed that the concentrations of the species in the fly ashes vary. For instance, the concentration of $\mathrm{Ca}$ and $\mathrm{Mg}$ in SC fly ash was found to be higher than their concentration in $\mathrm{TC}$ fly ash. The variation in the concentrations of $\mathrm{Ca}$ and $\mathrm{Mg}$ in the fly ashes could be due to the different types of coal burnt by the different power 
stations. The concentration and the dissolution of the oxides of $\mathrm{Ca}$ and $\mathrm{Mg}$ in the fly ash have significant effect on the $\mathrm{pH}$ of the fly ash system. This effect was noticed in the $\mathrm{pH}$ of the two fly ash systems as the $\mathrm{pH}$ of $\mathrm{SC}$ fly ash, with higher concentration of $\mathrm{Ca}$ and $\mathrm{Mg}$, was slightly higher than that of TC fly ash (Fig. 2). The higher concentration of $\mathrm{S}$ and $\mathrm{Cl}$ in the TC fly ash compared to their concentration in SC fly ash could be attributed to the pre-conditioning of the TC fly ash with brine solution before the sample was taken.

\section{$3.2 \mathrm{pH}$ and EC}

The $\mathrm{pH}$ and $\mathrm{EC}$ of $\mathrm{SC}$ and $\mathrm{TC}$ fly ash-brine interactions in the up-flow percolation test are shown in Fig. 2. The pH of the unreacted brine (UB) was $\approx 8$. After the interaction of the brine solution with the fly ashes, the $\mathrm{pH}$ of the fly ash-brine systems increased significantly to values $>13$ and $>12$ in SC and TC systems, respectively (Fig. 2) at the beginning of the experiments except for TC fly ash-brine system at L/S 0.1 where the $\mathrm{pH}$ value at the beginning of the experiment was almost the same as the $\mathrm{pH}$ of the UB. The high $\mathrm{pH}$ values observed in the leachates of the up-flow percolation systems during the first few bed volumes of flow could be attributed to the dissolution and hydrolysis of alkalinity-contributing oxides such as $\mathrm{CaO}$ on the surface of the fly ash particles during the 3-day equilibration period (Gitari et al. 2009; Iwashita et al. 2005; Reardon et al. 1995). After the initial increase, the $\mathrm{pH}$ of the systems (Fig. 2) gradually decreased over several bed volumes of flow. The gradual decrease in the $\mathrm{pH}$ of the systems after the maximum $\mathrm{pH}$ was reached at $\mathrm{L} / \mathrm{S}$ o.5 could be due to the slow release and continuous flushing out of the dissolved alkalinitycontributing components as a result of the low flow rate $(12 \mathrm{~mL} / \mathrm{h})$ applied in the systems.

Table 1 Major elements in SC and TC fly ashes

\begin{tabular}{llllllr}
\hline Major species (ppm) & Al & Ca & Mg & Na & Si & S \\
\hline SC fly ash & 137,751 & 66,467 & 13,572 & 4,525 & 231,787 & $1,378.35$ \\
TC fly ash & 129,495 & 42,096 & 8,204 & 2,151 & 242,352 & $7,025.05$ \\
\hline
\end{tabular}




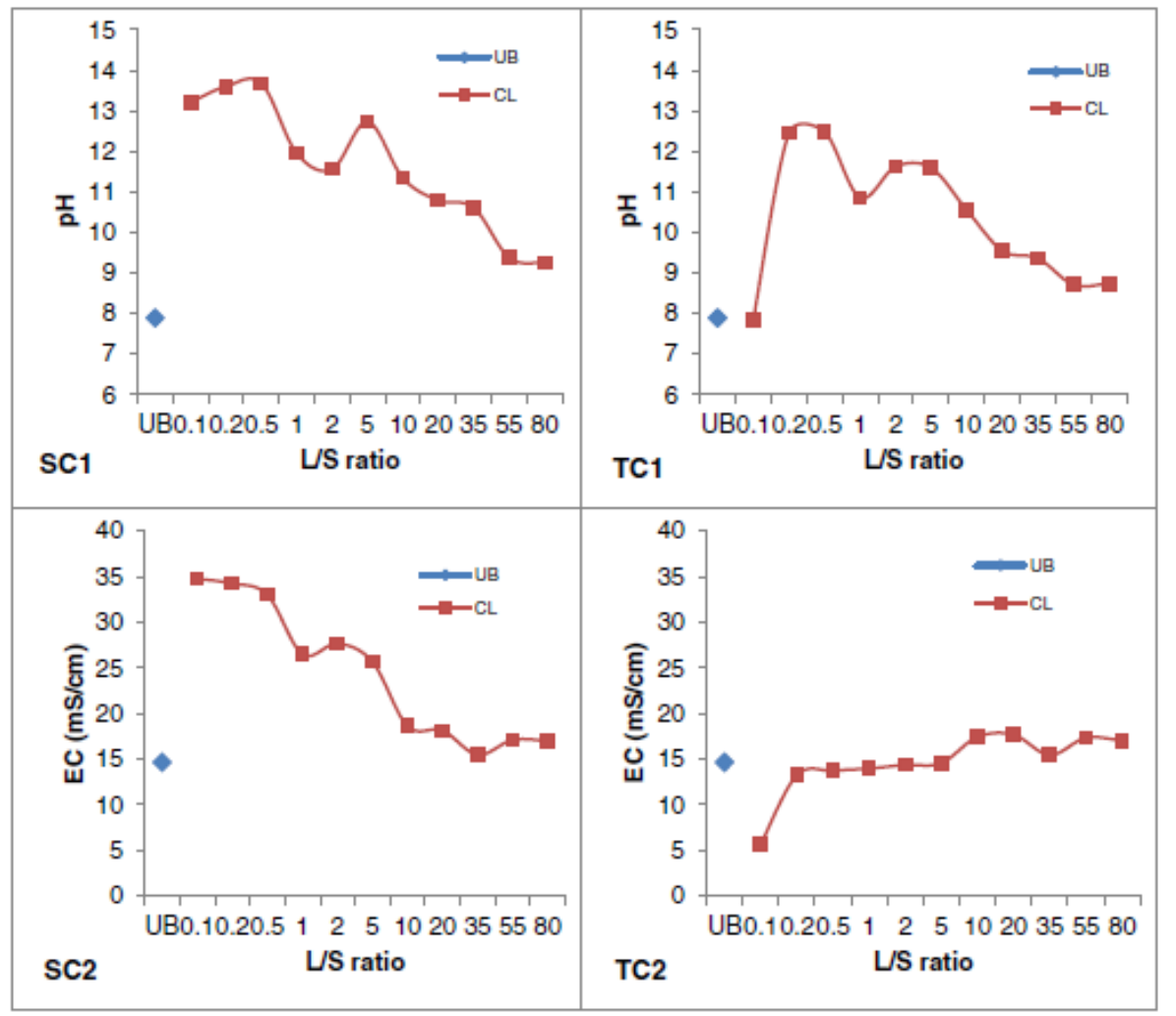

Fig. $2 \mathrm{pH}$ (SC1 and TC1) and EC (SC2 and TC2) profiles of up-flow percolation tests as a function of $\mathrm{L} / \mathrm{S}$ ratio: $U B=$ unreacted brine, $C L=$ fly ash-brine leaching trend

After the 3-day equilibration period, the EC of TC systems (Fig. 2 (TC2)) was initially considerably lower $(5.6 \mathrm{mS} / \mathrm{cm})$ than the EC of the unreacted brine solutions (UB) at the beginning of the test. Thereafter, the EC of TC systems increased rapidly to $13.23 \mathrm{mS} / \mathrm{cm}$ at L/S 0.2 after which a gradual and steady increase was observed until the end of the test except at L/S 35 where a slight decrease in the EC values of the fly ash-brine systems were observed. On the other hand, the EC of SC systems (Fig. 2 (SC2)) increased from $\approx 15$ $\mathrm{mS} / \mathrm{cm}$ to the maximum of between $30-35 \mathrm{mS} / \mathrm{cm}$ at the beginning of the percolation test (after the equilibration) after which a gradual decrease from 35 to $15 \mathrm{mS} / \mathrm{cm}$ in the EC trends was observed for the fly ash-brine systems. The low EC values observed in TC systems at the beginning of the test could be attributed to the removal of some major species such as $\mathrm{Na}, \mathrm{Cl}$ and $\mathrm{SO}_{4}$ from the fly ash-brine systems upon the initial contact of the fly ash with brine which was confirmed by the analysis of the eluate. The initial removal observed could be as a result of transient precipitation of some elements or formation of secondary mineral phases due to the super-saturation of these species in the systems. The rapid increase observed in the EC thereafter could be attributed to the dissolution of the transient phases or the dissolution of major components from the matrix of the fly ash that were released over time as the $\mathrm{pH}$ decreased. In contrast to the TC systems where the EC increased steadily, the EC of SC systems decreased steadily from about 35 to $15 \mathrm{mS} / \mathrm{cm}$. The high EC observed at the beginning of the test, in the case of the SC system (Fig. 2 (SC2)), could be accounted for by the dissolution of highly soluble components of the fly ash during the 3-day equilibration period. The gradual decrease in the EC as observed in SC 
system could indicate the steady flushing out of the dissolved species from the ash or the precipitation of some of the dissolved species due to super-saturation promoted by continuous and gradual flow of fresh brine solution in the systems. The almost stable EC observed at the end of the tests (Fig. 2) could be attributed to the steady and continuous dissolution of components locked up in the aluminosilicate matrix that are released over time.

\subsection{Major Elements in the Fly Ash-Brine Leachates}

The concentration of $\mathrm{Al}$ in the leachate samples collected from $\mathrm{SC}$ up-flow percolation systems (Fig. 3 ( $\left.\mathrm{SC}_{3}\right)$ ) was between 1 and $2 \mathrm{mg} / \mathrm{L}$ after the equilibration whereas the concentration of $\mathrm{Al}$ in the unreacted brine solutions at the beginning of the up-flow percolation tests was almost zero. This indicates that $\mathrm{Al}$ was released from fly ash upon equilibration with brine. The concentration of $\mathrm{Al}$ in $\mathrm{SC}$ leachate (Fig. 3 ( $\left.\mathrm{SC}_{3}\right)$ ) thereafter reduced to a minimum at $\mathrm{L} / \mathrm{S} 1$ and 2 whereafter an increase to about $4 \mathrm{mg} / \mathrm{L}$ was observed at $\mathrm{L} / \mathrm{S} 10$ after which the concentration of $\mathrm{Al}$ gradually decreased in the systems for the remaining L/S ratio. The release of $\mathrm{Al}$ in leachates samples of TC systems (Fig. 3 (TC3)) was higher (about $18 \mathrm{mg} / \mathrm{L}$ ) thus more $\mathrm{Al}$ was released from the TC fly ash after equilibration at the beginning of the test. After the increase observed during equilibration, a gradual decrease in $\mathrm{Al}$ concentration was observed in TC leachates (Fig. 3 (TC3)) and continued until the end of the up-flow percolation tests. The leaching patterns of $\mathrm{Al}$ could be attributed to the dissolution of its oxides as a result of flushing out of $\mathrm{Al}$ due to continuous inflow of brine solution. The slight increase observed in the concentration of $\mathrm{Al}$ in $\mathrm{SC}_{3}$ leachates at the beginning of the tests could be attributed to the dissolution of amorphous aluminosilicates in the fly ash. In fly ash systems, it was argued that after the rapid dissolution of $\mathrm{CaO}$ and other soluble salts, the mineral phase most susceptible to weathering are amorphous glassy aluminosilicates and silica (Seoane and Leirós 2001). The decrease observed at L/S 1 to 5 in $\mathrm{SC}_{3}$ could be as a result of formation of transient phases (Hyks et al. 2009; Georgakopoulos et al. 2002; Tiruta-Barna et al. 2006) due to high $\mathrm{pH}$ of the up-flow percolation systems. 


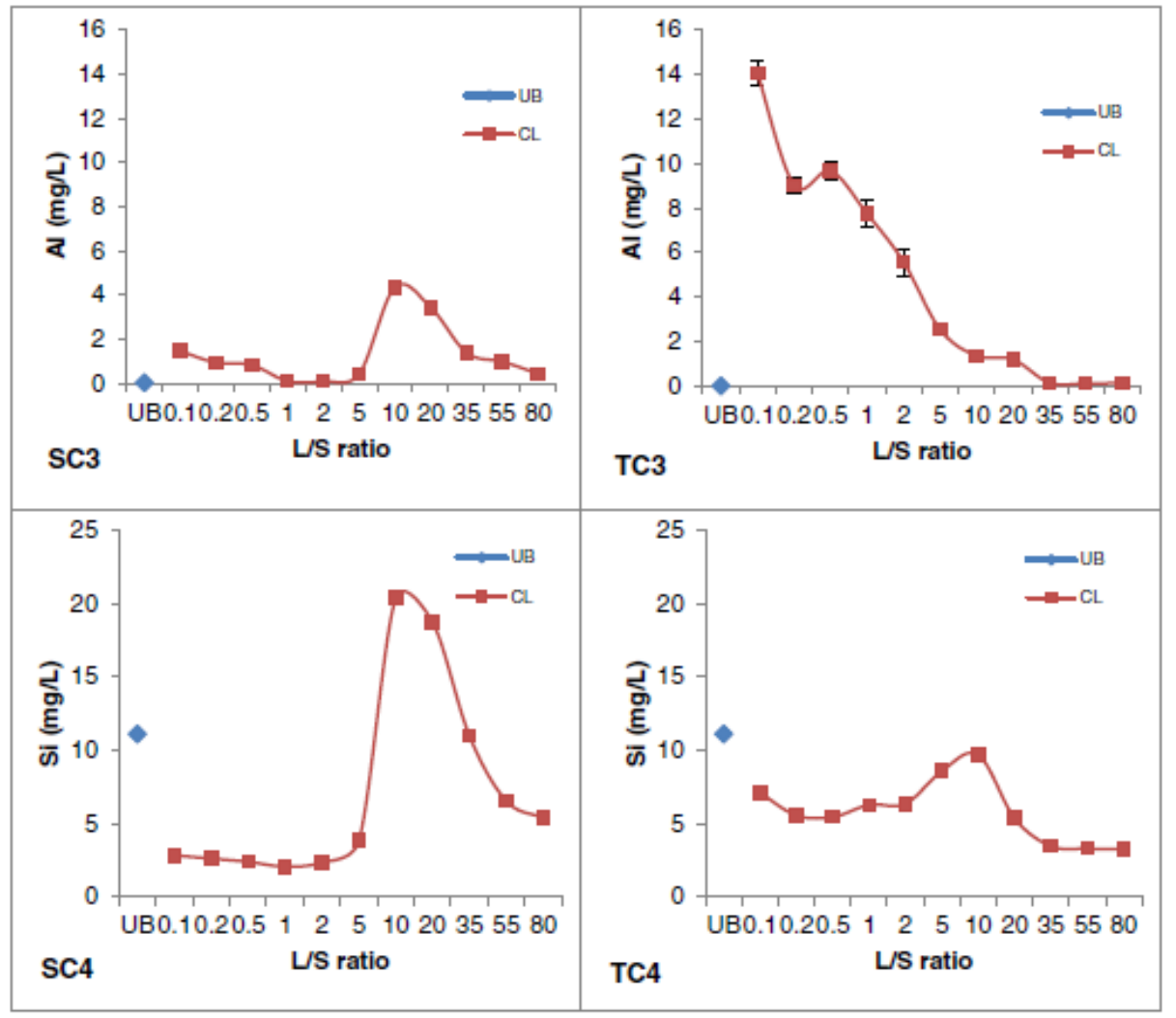

Fig. 3 The concentrations of $\mathrm{Al}$ (SC3 and TC3) and $\mathrm{Si}$ (SC4 and TC4) released from the up-flow percolation tests as a function of L/S ratio: $U B=$ unreacted brine, $C L=$ fly ash-brine leaching trend

The sudden increase observed at $\mathrm{L} / \mathrm{S} 10$ in $\mathrm{SC}_{3}$ could be accounted for by the dissolution of the transient or by further dissolution of the glassy $\mathrm{Al}$ phases. The difference observed in the leaching trend of $\mathrm{Al}$ in $\mathrm{TC}$ systems ( $\mathrm{TC}_{3}$ ) compared to that of $\mathrm{SC}$ systems ( $\mathrm{SC}_{3}$ ) could be as a result of the lower $\mathrm{pH}$ of the former due to the dust suppression pretreatment it underwent before the sample was taken. The higher concentration of $\mathrm{Al}$ in $\mathrm{TC}$ systems $\left(\mathrm{TC}_{3}\right)$ at the beginning of the tests could be as a result of the greater solubility of the amorphous glassy or crystalline $\mathrm{Al}$ phases in the fly ash due to the lower $\mathrm{pH}$ of TC systems.

The release of $\mathrm{Si}$ in both $\mathrm{SC}$ and TC systems (Fig. 3 ( $\mathrm{SC}_{4}$ and $\mathrm{TC} 4$ )) followed nearly the same trend. The concentration of $\mathrm{Si}$ at the beginning of the tests (L/S o.1-2) was observed to be lower than the Si concentration in UB which indicates that $\mathrm{Si}$ was removed from the brine solution during equilibration. The removal of $\mathrm{Si}$ at the beginning of the tests could be due to the formation of transient amorphous Si-bearing mineral phases. Georgakopoulos et al. (2002) suggested that the presence of $\mathrm{Al}$ and $\mathrm{Si}$ in solution at high $\mathrm{pH}$ could lead to the formation of amorphous $\mathrm{Al}$ hydroxides and Si-rich mineral phases such as gehlenite $\left(\mathrm{Ca}_{2} \mathrm{Al}_{2} \mathrm{SiO}_{73} \mathrm{SiO}_{5}\right)$ and hatrurite $\left(\mathrm{Ca}_{3} \mathrm{SiO}_{5}\right)$. The formation of these phases may be possible due to the significant concentration of $\mathrm{Ca}$ released into the up-flow percolation systems. A rapid increase in $\mathrm{Si}$ concentration was observed at $\mathrm{L} / \mathrm{S} 5^{-20}$ and 2-10 in SC and TC systems, respectively (Fig. 3 ( $\mathrm{SC}_{4}$ and $\left.\mathrm{TC} 4\right)$ ), with more Si released from SC fly ash ( $\approx 15$ $\mathrm{mg} / \mathrm{L})$ than TC fly ash $(\approx 6 \mathrm{mg} / \mathrm{L})$. The increase in both systems could be accounted for by the dissolution of the probable transient secondary mineral phases formed or as a result of 
the further dissolution of the silica matrix of the fly ash (Jankowski et al. 2006; Ward et al. 2009) in case of SC systems ( $\mathrm{SC}_{4}$ ). In the case of TC systems (TC4), the dissolution of some transient amorphous silica containing phases formed at the beginning of the tests could possibly account for the increase at L/S 5 and 10. This assumption was based on the fact that despite the increase in the concentration of $\mathrm{Si}$ at $\mathrm{L} / \mathrm{S} 2-10$ in $\mathrm{TC}$ systems (TC4), the concentration of $\mathrm{Si}$ in $\mathrm{TC}$ systems remained lower than its concentration in the UB.

The concentration of $\mathrm{Ca}$ in $\mathrm{UB}$ was about $91 \mathrm{mg} / \mathrm{L}$ while $\mathrm{SO}_{4}$ levels in UB were exceptionally high, being nearly 9,000 mg/L (Fig. 4). The concentration of Ca in leachates from both SC and $\mathrm{TC}$ up-flow percolation systems (Fig. 4 ( $\mathrm{SC}_{5}$ and $\left.\mathrm{TC}_{5}\right)$ ) increased after equilibration at the beginning of the tests (L/S o.1) compared with its concentration in the unreacted brine solutions. The concentration of $\mathrm{Ca}$ in the leachates gradually increased until a maximum of about 500 and $350 \mathrm{mg} / \mathrm{L}$ was reached at L/S 55 and $5 \mathrm{in} \mathrm{SC}$ and TC systems, respectively. The trend of $\mathrm{Ca}$ released from the fly ash-brine systems showed that apart from the initial dissolution of readily soluble Ca-rich phases such as $\mathrm{CaO}$, the dissolution of Ca-rich phases locked in the fly ash matrix contributed significantly to the gradual increase in Ca concentration. The fluctuation in the concentration of $\mathrm{Ca}$ in the SC systems and the gradual decrease observed in TC systems (Fig. 4 ( $\mathrm{TC}_{5}$ )) after the maximum was reached at L/S 5 could be as a result of depletion of Ca-bearing phases by flushing with brine solution or due to precipitation and dissolution of transient Ca-rich mineral phases in the fly ash-brine systems (Georgakopoulos et al. 2002; Hjelmar 1990). Steenari et al. (1999) suggested that the presence of other species such as $\mathrm{SO}_{4}$ in alkaline fly ash systems could produce Ca-hydrated mineral phases such as gypsum and calcite. Ca in fly ash occurs mainly as lime $(\mathrm{CaO})$, anhydrite $\left(\mathrm{CaSO}_{4}\right)$ and in the glass matrix, and these anhydrous phases are very reactive when exposed to aqueous solution. Therefore, the solubility and reactivity of $\mathrm{Ca}$ with other species could be responsible for the trend of Ca observed in leachates in the up-flow percolation systems.

The very high concentration of $\mathrm{SO}_{4}$ in the leachates from both $\mathrm{SC}$ and $\mathrm{TC}$ systems showed a very significant decrease after equilibration at the beginning of the up-flow percolation tests compared to the concentration of $\mathrm{SO}_{4}$ in the unreacted brine solutions (UB) (Fig. 4 (SC6 and TC6)). This indicates that $\mathrm{SO}_{4}$ was significantly removed from the brine during and after the equilibration until 1 bed volume of brine had percolated. The concentration of $\mathrm{SO}_{4}$ removed from the brine solution by the fly ashes immediately after equilibration (at $\mathrm{L} / \mathrm{S}$ 0.1) was between 6,000 and $8,000 \mathrm{mg} / \mathrm{L}$. After the very low concentration of $\mathrm{SO}_{4}$ observed in the leachates at the beginning of the tests, the $\mathrm{SO}_{4}$ concentration increased again until a maximum (between 7,000 and 8,000 $\mathrm{mg} / \mathrm{L}$ ) was observed at $\mathrm{L} / \mathrm{S} 20$ and 10 in SC and TC up-flow percolation systems, respectively (Fig. 4 (SC6 and TC6)). 


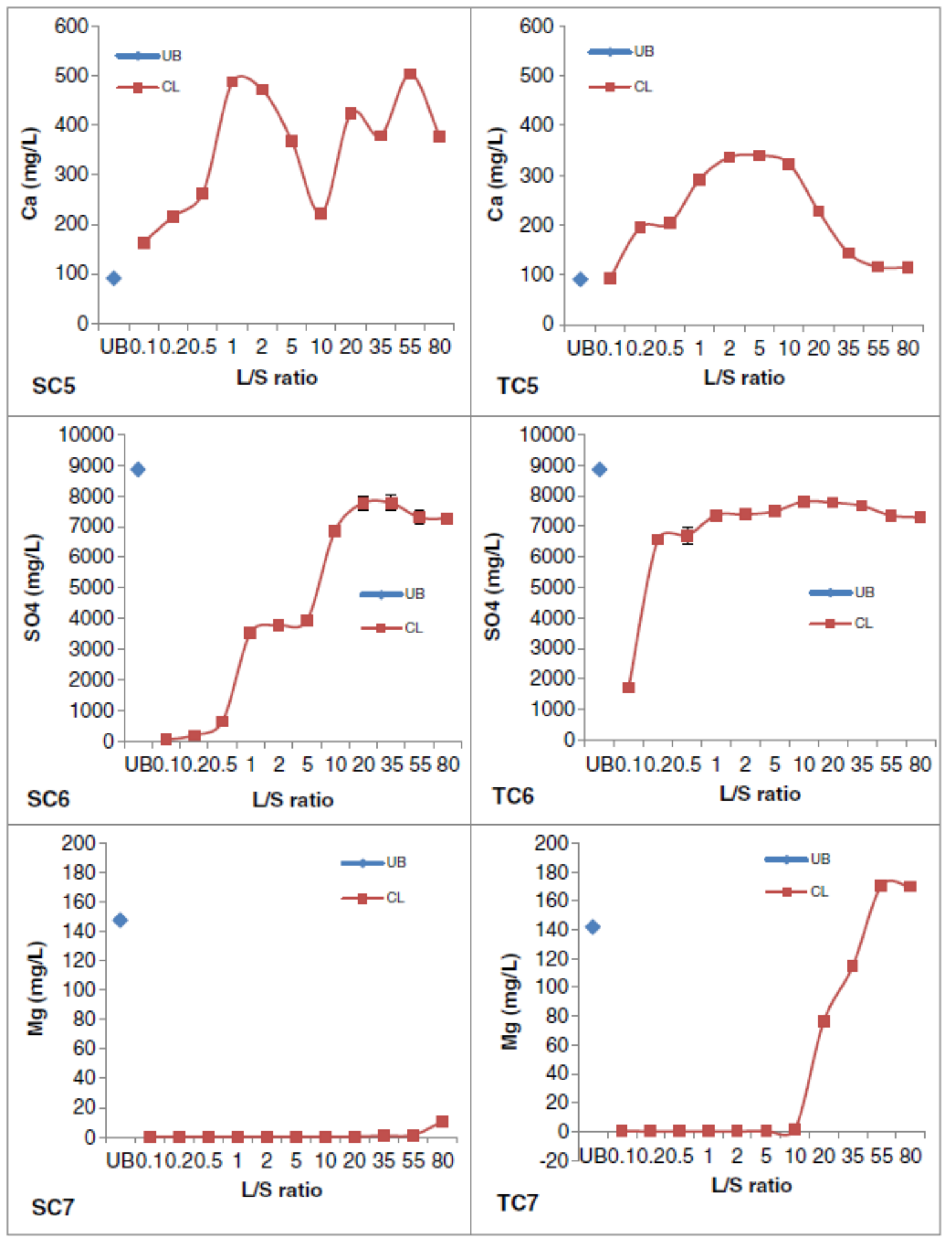

Fig. 4 The concentrations of $\mathrm{Ca}$ (SC5 and TC5), $\mathrm{SO}_{4}$ (SC6 and TC6) and $\mathrm{Mg}$ (SC7 and TC7) released from the up-flow percolation tests as a function of $\mathrm{L} / \mathrm{S}$ ratio: $U B=$ unreacted brine, $C L=$ fly ash-brine leaching trend

The trends of $\mathrm{SO}_{4}$ showed that $\mathrm{SO}_{4}$ the brine solutions by the fly ashes as a result of precipitation of $\mathrm{SO}_{4}$ bearing phases. According to Bock (1961), in a system containing considerable concentration of $\mathrm{Ca}$ and $\mathrm{SO}_{4}$, the precipitation of gypsum $\left(\mathrm{CaSO}_{4} \cdot 2 \mathrm{H}_{2} \mathrm{O}\right)$ could control the release of $\mathrm{SO}_{4}$ but when the solution contains excess of $\mathrm{Na}$ or $\mathrm{KCl}$, 
the precipitation of anhydrite is possible only at high temperature. The removal of $\mathrm{SO}_{4}$ from the fly ash-brine systems especially at the beginning of the tests could be attributed to the formation of transient $\mathrm{CaSO}_{4}$-rich mineral phases such as gypsum (Gitari et al. 2009). The significant amounts of $\mathrm{SO}_{4}$ present in the brine solution could interact with the Ca released from the fly ashes during equilibration to form transient $\mathrm{CaSO}_{4}$-rich mineral phases. Gypsum is moderately soluble in water or in aqueous solution. The gradual dissolution of the transient hydrated $\mathrm{CaSO}_{4}$-rich phase formed at the beginning of the tests (during equilibration period) could be responsible for the increase in the concentration of $\mathrm{SO}_{4}$ in the leachates after the initial minimum concentration. This shows that the mineral phases formed are unstable and subject to continuous weathering if an excess of brine (more that $\mathrm{L} / \mathrm{S} 1$ ) is percolated through the ash system.

The concentration of $\mathrm{Mg}$ in the UB was approximately $140 \mathrm{mg} / \mathrm{L}$ (Fig. 4 ( $\mathrm{SC}_{7}$ and $\mathrm{TC} 7$ )). The concentration of $\mathrm{Mg}$ in the leachates of the up-flow percolation systems indicates the immediate and constant removal of approximately $140 \mathrm{mg} / \mathrm{L} \mathrm{Mg}$ from the brine solutions during the interactions with the fly ashes despite the continuous inflow of the fresh brine solutions (Fig. 4 ( $\mathrm{SC}_{7}$ and $\left.\mathrm{TC}_{7}\right)$ ). An increase in the concentration of $\mathrm{Mg}$ was observed at $\mathrm{L} / \mathrm{S} 55$ and 10 in $\mathrm{SC}\left(\mathrm{SC}_{7}\right)$ and $\mathrm{TC}\left(\mathrm{TC}_{7}\right)$ up-flow percolation systems, respectively. The low concentration of $\mathrm{Mg}$ which indicates its continuous removal by the fly ash in the system could be attributed to the formation of Mg-rich mineral phases such as $\mathrm{Mg}(\mathrm{OH})_{2}$ due to the alkaline $\mathrm{pH}$ of the systems which favours the formation of such mineral phases. The hydrolysis of $\mathrm{MgO}$ in fly ash in alkaline condition has been observed to form sparingly soluble brucite $\left(\mathrm{Mg}(\mathrm{OH})_{2}\right)$ (TirutaBarna et al. 2006; Warren and Dudas 1984), and this could account for the low level of $\mathrm{Mg}$ in the leachates of the up-flow percolation tests. Apart from $\mathrm{MgO}$ present on the surface of fly ash, $\mathrm{Mg}$ is also present in the slowly dissolving glassy phase (Mattigod et al. 1990), and this could account for the gradual increase observed in $\mathrm{Mg}$ concentration in the leachates above levels found in UB over time at L/S 55 in $\mathrm{TC}(\mathrm{TC} 7)$ systems.

$\mathrm{Na}$ concentration was very high in $\mathrm{UB}$, being approximately 4,323 $\mathrm{mg} / \mathrm{L}$ while $\mathrm{Cl}$ level was also high $(2,424 \mathrm{mg} / \mathrm{L})$. Two different trends were observed for the release of $\mathrm{Na}$ into the leachates from SC and TC up-flow percolation systems (Fig. 5 (SC8 and TC8)). A slight increase in the concentration of $\mathrm{Na}$ (approximately 5,000 $\mathrm{mg} / \mathrm{L}$ ) was observed in SC systems (SC8) after equilibration while initially, at L/S 0.1, a significant decrease to about $1,000 \mathrm{mg} / \mathrm{L}$ in $\mathrm{Na}$ concentration was observed in TC (TC8) systems immediately after equilibration and at the beginning of the up-flow percolation tests. After the initial increase in the concentration of $\mathrm{Na}$ in SC system, a slight and slow decrease (only slightly lower than the levels in UB) was observed and this concentration $(>4,000 \mathrm{mg} / \mathrm{L})$ was maintained throughout the period of the tests. On the other hand in the TC systems, the concentration of $\mathrm{Na}$ increased abruptly at L/S 0.2 from approximately $1,000 \mathrm{mg} / \mathrm{L}$ to $4,000 \mathrm{mg} / \mathrm{L}$ and was almost equal to its 
concentration in UB throughout the percolation tests with small fluctuation except at $\mathrm{L} / \mathrm{S} 35$ where a slight decrease in the concentration was observed. The slight increase of $\mathrm{Na}$ at L/S 0.1 in SC systems when compared with the concentration in UB could be attributed to the leaching of $\mathrm{Na}$ from the fly ash during the 3-day equilibration period while the initial decrease in Na concentration in TC systems immediately after the equilibration period may be as a result of the formation of transient Na-containing phase upon contact with fly ash due to the super-saturation of $\mathrm{Na}$ in the brine containing systems. The nearly immediate dissolution of the transient Na-containing phase or the exhaustion of the capacity of the fly ash to capture more $\mathrm{Na}$ from the brine due to continuous flow of brine may account for the increase in $\mathrm{Na}$ concentration in $\mathrm{TC}$ systems at L/S 0.2. These trends indicate that after the initial removal of $\mathrm{Na}$, the capacity of the fly ashes to remove more $\mathrm{Na}$ from the brine solutions during the tests reduced as a result of continuous flow of fresh brine solution. This shows that the removal of $\mathrm{Na}$ from the brine solution is insignificant.

The concentration of $\mathrm{Cl}$ in the leachates after contact with fly ash was lower than the concentration in UB throughout the period of the up-flow percolation tests (Fig. 5 (SC9 and TC9)). This indicates that some $\mathrm{Cl}$ was continuously removed from the brine solution throughout the period of the up-flow percolation tests.

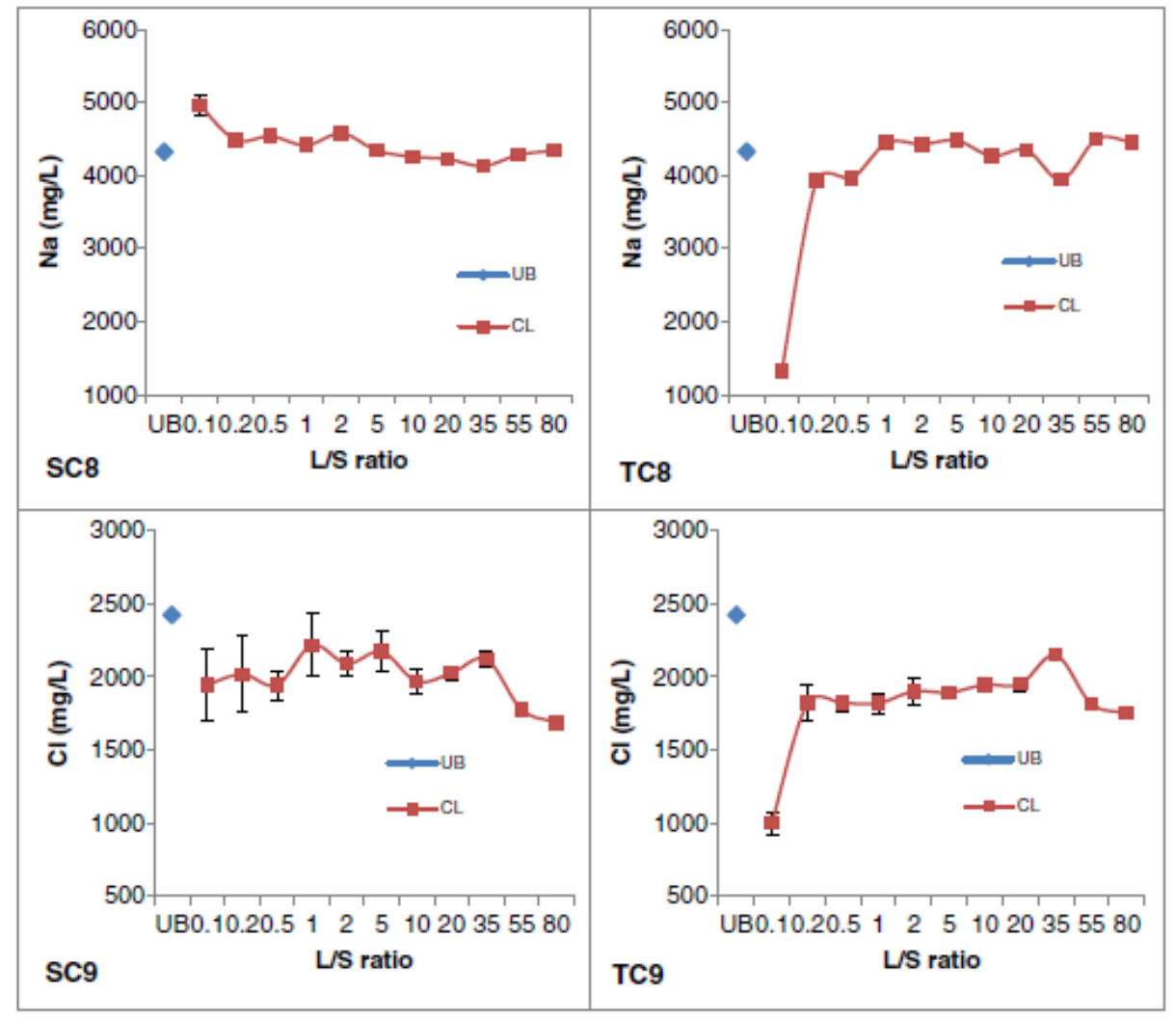

Fig. 5 The concentrations of $\mathrm{Na}$ (SC8 and TC8) and $\mathrm{Cl}$ (SC9 and TC9) released from the up-flow percolation tests as a function of L/S ratio: $U B=$ unreacted brine, $C L=$ fly ash-brine leaching trend 
$\mathrm{Cl}$ was initially removed from the brine solution in TC systems after equilibration. Between L/S 0.1 and 0.2, a proportion of the $\mathrm{Cl}$ removed from TC systems was redissolved and the levels increased from about $1,000 \mathrm{mg} / \mathrm{L}$ to about $2,000 \mathrm{mg} / \mathrm{L}$ for the duration of the experiments with small fluctuation. The removal patterns of $\mathrm{Cl}$ in $\mathrm{TC}$ systems correlated with those of $\mathrm{Na}$ indicating that the removal of $\mathrm{Cl}$ from the systems could be controlled by the formation of a transient halite $(\mathrm{NaCl})$ phase at the beginning of the tests. Due to the sufficient concentration of $\mathrm{Ca}$ and $\mathrm{Al}$ in the up-flow percolation systems as a result of matrix dissolution of fly ash, the probable formation of Friedel's salt $\left[\mathrm{Ca}_{4} \mathrm{Al}_{2} \mathrm{Cl}_{2}(\mathrm{OH})_{12} \cdot 4 \mathrm{H}_{2} \mathrm{O}\right]$ could also account for the reduction in the concentration of $\mathrm{Cl}$ after the initial stages in the systems (Hyks et al. 2009; Suryavanshi and Swamy 1996; Bothe and Brown 2004).

\subsection{Mass Balance}

The percentage of species leached from the fly ashes or removed from the brine solution (UB) at selected L/S ratios during the up-flow percolation tests are presented in Tables 2 and 3. The percent leached or removal of the species was calculated using the following equation;

$$
\% \text { Removal } / \text { Leached }=\frac{\text { CUB }-\mathrm{CL}}{\mathrm{CUB}} \times 100
$$

where

CUB is the concentration of species in the unreacted brine (UB)

$\mathrm{CL}$ is the concentration of species in the leachate that percolated through the ash

The calculated mass balance (Tables 2 and 3) revealed that the removal of Na, mostly at the beginning of the experiment, was low, in the range of $2.3 \%$ except in the TC fly ashbrine system where $69.4 \%$ was only observed at $\mathrm{L} / \mathrm{S}$ o.1. The removal of $\mathrm{Mg}, \mathrm{Cl}$ and $\mathrm{SO}_{4}$ was in the range of 92-100, 8.5-30.3 and 12.3-99.4\%, respectively, in SC fly ash-brine system, while in the TC fly ash-brine system, the percentage removal of $\mathrm{Mg}, \mathrm{Cl}$ and $\mathrm{SO}_{4}$ was in the range of 99.7- 100, 19.5-58.8 and 12.3-80.7 \%, respectively, at different L/S ratios. The removal of some species from the brine solution at specific L/S ratio could be attributed to the precipitation process in the up-flow percolation systems. However, $\mathrm{Ca}$ and $\mathrm{Al}$ were leached out of the fly ashes into the brine solution in significant percentages irrespective of the $\mathrm{L} / \mathrm{S}$ ratio. 
Table 2 Chemical composition of brine and the percentage of major elements leached from fly ash or removed from brine during the upflow percolation tests on SC fly ash and brine at selected L/S ratios (All values are in percent except UB = milligram per litre)

\begin{tabular}{|c|c|c|c|c|c|c|c|}
\hline \multirow[t]{2}{*}{ Parameter } & \multirow[t]{2}{*}{ UB } & \multicolumn{6}{|l|}{$\mathrm{L} / \mathrm{S}$ ratio } \\
\hline & & 0.1 & 1 & 5 & 20 & 55 & 80 \\
\hline $\mathrm{Al}$ & 0.01 & $-13,016.3$ & -742.7 & $-3,698.8$ & $-30,671.8$ & $-8,634.9$ & $-3,803.8$ \\
\hline $\mathrm{Ca}$ & 91 & -79.7 & -435.1 & -304.6 & -365.2 & -452.3 & -315.1 \\
\hline $\mathrm{Mg}$ & 147.5 & 99.9 & 100 & 99.9 & 99.8 & 100 & 92.8 \\
\hline $\mathrm{Na}$ & $4,323.2$ & -14.9 & -2.1 & -0.5 & 2.3 & 0.9 & -0.4 \\
\hline $\mathrm{Si}$ & 11.1 & 74.6 & 81.5 & 65.7 & -68.9 & 41.1 & 51.6 \\
\hline $\mathrm{Cl}$ & 2424 & 19.7 & 8.5 & 10.3 & 16.3 & 26.6 & 30.3 \\
\hline $\mathrm{SO}_{4}$ & 8,858 & 99.4 & 60 & 55.6 & 12.3 & 17.6 & 18.1 \\
\hline
\end{tabular}

Negative ( - ) values indicate percent leached from the fly ash into the brine solution while the positive values indicate percent removal from the brine during the up-flow percolation tests

The removal capacity of the two fly ashes varied slightly. The percentage of some species such as $\mathrm{Mg}, \mathrm{Si}$ and $\mathrm{SO}_{4}$ removed from the brine solution by $\mathrm{SC}$ fly ash was higher than the percentage removed by TC fly ash in most cases. The increase in the removal capacity of SC fly ash could be attributed to its slightly higher $\mathrm{pH}$ than TC fly ash. The TC fly ash removed more $\mathrm{Na}$ and $\mathrm{Cl}$ from the brine solution than SC fly ash, which could be attributed to the effect of the super-saturation of these species bearing in mind that the TC fly ash had been moistened with brine before sampled.

\section{Conclusion}

The removal and subsequent leaching of some species in the systems could be as a result of precipitation followed by dissolution of the transient secondary mineral phases formed during the interactions. The release of $\mathrm{Ca}, \mathrm{Al}$ and $\mathrm{Na}$ throughout the period of the percolation tests indicates that these species would continuously leach from the fly ashes by contact with brine flows. The trends observed in the release of the major species from the up-flow percolation systems showed that the removal capacity of the fly ashes could be exhausted at a stage due to continuous inflow of brine thereby overwhelming the removal of some species by the fly ashes. 
Table 3 Chemical composition of brine and the percentage of major elements leached from fly ash or removed from brine during the upflow percolation tests on TC fly ash and brine at selected L/S ratios (All values are in percent except UB = milligram per litre)

\begin{tabular}{|c|c|c|c|c|c|c|c|}
\hline \multirow[t]{2}{*}{ Parameter } & \multirow[t]{2}{*}{ UB } & \multicolumn{6}{|l|}{$\mathrm{L} / \mathrm{S}$ ratio } \\
\hline & & 0.1 & 1 & 5 & 20 & 55 & 80 \\
\hline $\mathrm{Al}$ & 0.01 & $-126,062.4$ & $-69,417.1$ & $-22,863.1$ & $-10,734.6$ & $-1,080.4$ & $-1,186$ \\
\hline $\mathrm{Ca}$ & 91 & -2.2 & -220.6 & -273.3 & -150.2 & -27.4 & -26.4 \\
\hline $\mathrm{Mg}$ & 147.5 & 99.8 & 99.9 & 99.7 & 100 & 100 & 100 \\
\hline $\mathrm{Na}$ & $4,323.2$ & 69.4 & -2.8 & -3.6 & -0.6 & -4.1 & -3.2 \\
\hline $\mathrm{Si}$ & 11.1 & 35.9 & 43.6 & 22.7 & 51.8 & 70.5 & 70.8 \\
\hline $\mathrm{Cl}$ & 2,424 & 58.8 & 24.9 & 21.8 & 19.5 & 25 & 27.7 \\
\hline $\mathrm{SO}_{4}$ & 8,858 & 80.7 & 16.9 & 15.5 & 12.3 & 17 & 17.8 \\
\hline
\end{tabular}

Negative (-) values indicate percent leached from the fly ash into the brine solution while the positive values indicate percent removal from the brine during the up-flow percolation tests

Apart from the reduction in the capacity of the fly ash to remove species from brine, metals held in the fly ash matrix could be released over time by brine flowing continuously through the ash system thereby increase the leaching of some species. The trend of the mobility of the major species in the fly ash-brine systems gives an insight into the long-term environmental effect of co-disposal technique. Hence, the co-disposal of brine with fly ash would require a careful consideration of the bed volume of brine that goes into the ash systems.

\section{Acknowledgments}

Gratitude goes to SASOL and ESKOM power utilities for providing financial support. The authors are grateful to the Chemistry Department of the University of the Western Cape, South Africa. 


\section{References}

Adriano, D. C., Page, A. L., Elseewi, A. A., Chang, A. C., \& Straughan, I. (1980). Utilization and disposal of fly ash and other coal residues in terrestrial ecosystems: a review. Journal of Environmental Quality, 9, 333-344.

American Coal Ash Association (ACAA) (2011). Coal Combustion Product (CCP) production \& use survey report. Website: http://www.acaa-usa.org. Accessed 30 April 2013.

Baba, A., \& Kaya, A. (2004). Leaching characteristics of solid wastes from thermal plants of western Turkey and comparison of toxicity methodologies. Journal of Environmental Management, 73, 199-207.

Bock, E. (1961). On the solubility of anhydrous calcium sulphate and of gypsum in concentrated solutions of sodium chloride at $25{ }^{\circ} \mathrm{C}, 30{ }^{\circ} \mathrm{C}, 40{ }^{\circ} \mathrm{C}$, and $50{ }^{\circ} \mathrm{C}$. Canadian Journal of Chemistry, 39, 1746-1751.

Bothe, J. V., \& Brown, P. W. (2004). PhreeqC modeling of Friedel's salt equilibria at $23 \pm 1$ degrees C. Cement and Concrete Research, 34(6), 1057-1063.

Comité Européen de Normalisation (CEN) (2003). prEN14405; leaching behaviour test-upflow percolation test- Horizontal standard, CEN TC292/WG6.

ESKOM Report (2013). Ash Management in ESKOM, Fact Sheet Number CO 0004. http://www.eskom.co.za. Accessed 22 March 2013.

Fatoba, O. O. (2010). Chemical interactions and mobility of species in fly ash-brine codisposal systems. PhD Dissertation, University of the Western Cape, South Africa.

Fatoba, O. O., Gitari, W. M., Petrik, L. F., \& Iwuoha, E. I. (2011). Fly ash-brine interactions: removal of major and trace elements from brine. Journal of Environmental Science and Health Part A, 46, 1648-1666.

Foner, A. H., Robl, L. T., Hower, C., \& Graham, M. U. (1999). Characterization of fly ash from Israel with reference to its possible utilization. Fuel, 78, 215-223.

Georgakopoulos, A., Filippidis, A., Kassoli-Fournaraki, A., Fernández-Turiel, J. L., Llorens, J., \& Mousty, F. (2002). Leachability of major and trace elements of fly ash from Ptolemais power stations, Northern Greece. Energy Sources, 24, 103-113.

Gitari, W. M., Petrik, L. F., Etchebers, O., Key, D. L., Iwuoha, E., \& Okujeni, C. (2006). Treatment of acid mine drainage with fly ash: removal of major contaminants and trace elements. Journal of Environmental Science and Health Part A, 41, 1729-1747.

Gitari, W. M., Fatoba, O. O., Petrik, L. F., \& Vadapalli, V. R. K. (2009). Leaching characteristics of selected South African fly ashes: effect of $\mathrm{pH}$ on the release of major and trace species. Journal of Environmental Science and Health Part A, 44(2), 206-220.

Hjelmar, O. (1990). Leachate from land disposal of coal fly ash. Waste Management \& Research, 8, 429-432.

Hyks, J., Astrup, T., \& Christensen, H. (2009). Long-term leaching from MSWI airpollution-control residues: leaching characterization and modeling. Journal of Hazardous Materials, 162, 80-91.

Ilic, M., Cheesman, C., Sollars, C., \& Knight, J. (2003). Mineralogy and microstructure of sintered lignite coal fly ash. Fuel, 82, 331-336. 
Iwashita, A., Sakaguchi, Y., Nakajima, T., Takanashi, H., Ohki, A., \& Kambara, S. (2005). Leaching characteristics of boron and selenium for various coal fly ashes. Fuel, 84, $479-485$.

Iyer, R. S., \& Scott, J. A. (2001). Power station fly ash-a review of value added utilization outside of the construction industry. Resources, Conservation and Recycling, 31, 217-228.

Jankowski, J., Ward, C. R., French, D., \& Groves, S. (2006). Mobility of trace elements from selected Australian fly ashes and its potential impact on aquatic ecosystems. Fuel, 85, 243-256.

Kumpiene, J., Lagerkvist, A., \& Maurice, C. (2006). Stabilization of $\mathrm{Pb}-$ and Cucontaminated soil using coal fly ash and peat. Environmental pollution, 145, 365373 .

Mattigod, S. V., Rai, D., Eary, L. E., \& Ainsworth, C. C. (1990). Geochemical factors controlling the mobilization of inorganic constituents from fossil fuel residues: I. Review of the major elements. Journal of Environmental Quality, 19, 188-201.

Meima, J. A., \& Comans, R. N. J. (1999). The leaching of trace elements from municipal solid waste incinerator bottom ash at different stages of weathering. Applied Geochemistry, 14, 159-171.

Polettini, A., \& Pomi, R. (2004). The leaching behaviour of incinerator bottom ash as affected by accelerated ageing. Journal of Hazardous Materials, 113, 209-215.

Reardon, E. J., Czank, C. A., Warren, C. J., Dayal, R., \& Johnston, H. M. (1995). Determining controls on element concentrations in fly ash leachate. Waste Management \& Research, 13, 435-450. 